\title{
Seasonality of caulerpenyne content in native Caulerpa prolifera and invasive $C$. taxifolia and $C$. racemosa var. cylindracea in the western Mediterranean Sea
}

\author{
Antonio Box ${ }^{1,3, *}$, Antoni Sureda ${ }^{2}$, Pere Tauler ${ }^{2}$, \\ Jorge Terrados ${ }^{3}$, Nuria Marbà ${ }^{3}$, Antoni Pons ${ }^{2}$ and \\ Salud Deudero ${ }^{1}$ \\ ${ }^{1}$ Laboratorio de Biología Marina, Departament de \\ Biología, Universitat de les Illes Balears, Ctra. \\ Valldemossa Km 7.5, 07122 Palma de Mallorca, Illes \\ Balears, Spain, e-mail: boxtoni@yahoo.es \\ ${ }^{2}$ Laboratori de Ciències de l'Activitat Física, Departament \\ de Biologia Fonamental i Ciències de la Salut, Universitat \\ de les Illes Balears, Ctra. Valldemossa Km 7.5, 07122 \\ Palma de Mallorca, Illes Balears, Spain \\ ${ }^{3}$ IMEDEA (CSIC-UIB) Instituto Mediterráneo de Estudios \\ Avanzados, C/Miquel Marqués 21, 07190 Esporles, \\ Mallorca, Illes Balears, Spain \\ * Corresponding author
}

\begin{abstract}
Fronds had higher mean caulerpenyne concentration than stolons in Caulerpa prolifera, C. taxifolia and C. racemosa. $C$. prolifera had higher mean caulerpenyne content [7.29 $\pm 0.64 \%$ caulerpenyne/frond dry weight (DW)] than $C$. taxifolia $(5.47 \pm 0.32 \%$ caulerpenyne/frond DW) and $C$. racemosa $(0.43 \pm 0.07 \%$ caulerpenyne/frond DW). C. prolifera had reduced content from May to October in fronds, with no clear seasonal pattern in stolons. C. taxifolia reached a maximum caulerpenyne value in fronds in May, with a slight decrease until the onset of winter; there was no clear seasonal trend in stolons. Caulerpenyne content remained relatively constant through the year in fronds of C. racemosa; stolons showed a clear seasonal pattern of increasing caulerpenyne content in spring, reaching maximum values at the end of summer, and decreasing during winter. $C$. prolifera caulerpenyne contents were positively correlated with densities of the Caulerpa-feeding gastropod Ascobulla fragilis $(\rho=0.84$, $\mathrm{p}<0.05$ ). The main finding of the present work is that $C$. prolifera has higher caulerpenyne concentrations than invasive Caulerpa species under similar climate conditions.
\end{abstract}

Keywords: algal toxins; Caulerpa; caulerpenyne; exotic species; toxicity.

\section{Introduction}

The presence of introduced species in marine ecosystems is an increasing problem around the world, and is related to the development of international shipping, aquaculture, and the aquarium trade (Verlaque and Fritayre 1994, Boudouresque et al. 1995, Boudouresque 1998, Boudouresque and Verlaque 2002). An introduced species is considered as invasive when self-sustaining populations outside its native area spread and are able to modify the structure of the invaded ecosystems causing ecological and/or economic impact (Sakai et al. 2001, Boudouresque and Verlaque 2002). Escape from biotic constraints (competitors, predators, grazers, parasites) may be one of the mechanisms by which introduced species become successful invaders (Mack et al. 2000, Sakai et al. 2001)

Several macroalgae can deter herbivores by using chemical defenses (Hay and Fenical 1988, Erickson et al. 2006). Species of the order Caulerpales (Chlorophyta) produce sesquiterpenoid and diterpenoid compounds that are toxic and actively deter generalist herbivores (Paul and Fenical 1986, Hay and Fenical 1988, Paul and Van Alstyne 1992). Caulerpenyne is a secondary metabolite synthesized by species of the genus Caulerpa; it plays a major role in their chemical defence (Paul and Fenical 1986, Pohnert and Jung 2003) against epiphytes and herbivores (Erickson et al. 2006). Caulerpenyne has also cytotoxic effects on mammalian cells (Parent-Massin et al. 1996, Barbier et al. 2001), inhibits the growth of marine fungi (Paul and Fenical 1986), interferes with the sexual reproduction of sea urchins at different stages (Paul and Fenical 1986, Lemee et al. 1996, Pesando et al. 1996), deters herbivory by gastropods and fishes, and is toxic to fishes (Paul and Fenical 1986). There are examples, however, in which caulerpenyne does not deter fish grazing (Meyer and Paul 1992), indicating that the toxicity is not intrinsic to the compound, but is a result of metabolite-consumer interactions (Paul 1992). Recent studies demonstrated that caulerpenyne is transformed into more toxic and deterrent oxytoxins when the algae are wounded (Gavagnin et al. 1994, Jung and Pohnert 2001). For instance, caulerpenyne has been shown to act as inducer of antioxidant response in the Mediterranean labrid Coris julis (Linnaeus) (Sureda et al. 2006).

Three species of Caulerpa are present in the western Mediterranean, C. prolifera (Forsskål) Lamouroux, C. taxifolia (Vahl) C. Agardh, and C. racemosa var. cylindracea (Sonder) Verlaque, Huisman et Boudouresque. C. prolifera is native and widely distributed throughout the Mediterranean Sea. An aquarium-maintained strain of C. taxifolia was introduced in the Mediterranean Sea in 1984 (Meinesz and Hesse 1991) and rapidly spread through the western basin (Meinesz et al. 2001). This species seems to interfere with vegetative development of the seagrass Posidonia oceanica L. Delile (Devillele and Verlaque 1995, Dumay et al. 2002) and reduces algal 
diversity of invaded communities (Balata et al. 2004, Verlaque et al. 2004); it has thereby greatly altered the Mediterranean shallow benthic communities in certain locations (Meinesz et al. 1993, Meinesz 2004). C. racemosa has been present in the eastern Mediterranean Sea since the early 20th century, likely to have been introduced from the Red Sea through the Suez Canal. However, it is the invasive $C$. racemosa var cylindracea variety, originally from southwestern Australia (Verlaque et al. 2003) that has rapidly spread throughout the western Mediterranean during the last 20 years (Verlaque et al. 2000), and has even reached the Canary Islands in the Atlantic Ocean (Verlaque et al. 2004). C. racemosa var cylindracea affects the development of seagrasses (Ceccherelli and Campo 2002, Dumay et al. 2002), reduces species richness and diversity of macroalgae in the invaded communities (Piazzi et al. 2001, Balata et al. 2004), and changes benthic invertebrate communities (Argyrou et al. 1999, Buia et al. 2001).

The aim of this study was to compare the caulerpenyne content of the native Caulerpa prolifera with those of the two invasive species of Caulerpa present in the Mediterranean Sea (C. taxifolia and C. racemosa var. cylindracea). We estimated the content of caulerpenyne at monthly intervals over one year taking into account previous studies showing that the content of caulerpenyne changes seasonally in Caulerpa species (Amade and Lemee 1998, Dumay et al. 2002), and evaluated its relationship to seasonal conditions reflected by seawater temperature, the biomass of Caulerpa, and the abundance of Caulerpa-specialized herbivores. The study was performed in three mixed Caulerpa-Posidonia oceanica meadows in Mallorca (Balearic Islands, western Mediterranean), all experiencing similar seasonal conditions.

\section{Materials and methods}

\section{Sampling locations}

Samples of Caulerpa species were collected monthly from November 2004 to October 2005 in Mallorca (Balearic Islands, western Mediterranean). Because the three Caulerpa species do not co-occur at any location off the island we chose two sampling locations: C. taxifolia and C. prolifera were collected in Cala D'Or Bay, off southeastern Mallorca $\left(39^{\circ} 22.164^{\prime} \mathrm{N} / 3^{\circ} 13.887^{\prime} \mathrm{E}\right.$ and $39^{\circ} 22.028^{\prime} \mathrm{N} / 3^{\circ} 13.739^{\prime} \mathrm{E}$, respectively), and C. racemosa var. cylindracea (hereafter $C$. racemosa) was collected in Portals Vells Bay, southwestern Mallorca ( $\left.39^{\circ} 28.321^{\prime} \mathrm{N} / 2^{\circ} 31.320^{\prime} \mathrm{E}\right)$. Both bays face east, and all the Caulerpa samples were collected at similar depth (5-6 m) over the rhizome mat of the seagrass Posidonia oceanica. This sampling design avoids the effect of depth on the caulerpenyne content of the three species. Seawater temperature was recorded with StowAway ${ }^{\circledR}$ Tidbit $^{\circledR}$ (Onset Computer Corporation, Pocasset, MA, USA) temperature loggers installed permanently at the sampling depths in both bays.

\section{Extraction and quantification of caulerpenyne}

Caulerpa species were visually identified and carefully handcollected by SCUBA divers to prevent the transformation of caulerpenyne into reactive aldehydes, a process driven by the fragmentation of the thallus (Gavagnin et al. 1994, Jung and Pohnert 2001). The algal material was maintained in fresh seawater at ambient temperature until the extraction of caulerpenyne (undertaken within $1 \mathrm{~h}$ of collection). In the laboratory, Caulerpa fragments were quickly washed in freshwater to remove external salt, dried with absorbent paper, and the fronds and stolons were separated. Each sample of fresh algal material [ $5 \mathrm{~g}$ wet weight $(\mathrm{WW})]$ was placed in $50 \mathrm{ml}$ of methanol for $24 \mathrm{~h}$ at $4^{\circ} \mathrm{C}$ to obtain the crude methanolic extract; for each sampling, five extracts (replicates) of each Caulerpa species and algal part (frond, stolon) were prepared. In addition, five replicate samples of $5 \mathrm{~g}$ (WW) of each Caulerpa species were dried at $70^{\circ} \mathrm{C}$ for $24 \mathrm{~h}$, then re-weighed to estimate the ratio of WW/dry weight (DW) and in order to compare the concentrations of caulerpenyne that were measured with values reported in the literature.

The methanolic extracts were filtered through silica columns and eluted with $5 \mathrm{ml}$ of a mixture of methanol/ethyl acetate (50:50). The concentration of caulerpenyne was determined using HPLC. The mobile phase consisted of 80:20 methanol/ $\mathrm{H}_{2} \mathrm{O}$. The HPLC was a Shimadzu (Shimadzu Europe, Duisburg, Germany) with a diode array detector, and the column was a Nova Pak $\mathrm{C}_{18}, 3.9 \times 150 \mathrm{~mm}$ (Waters HPLC columns, Dublin, Ireland). Caulerpenyne was determined at $254 \mathrm{~nm}$ and quantified by comparison with a standard curve of known concentrations. Pure caulerpenyne used to establish a standard curve was provided by Dr. P. Amade (Equipe Antitumoraux Naturels, Université Nice, Sophia Antipolis).

\section{Biomass of Caulerpa species and abundance of Caulerpa-specialized herbivores}

Biomass samples were collected from six quadrats of $20 \times 20 \mathrm{~cm}$ in $100 \%$ cover patches of each Caulerpa species on several dates during the study period (November, December 2004 and February, May, June, July, August, September and October 2005). Gaps in the sampling data (when compared with caulerpenyne assays) were due to the fact that these samples were initially collected for different purposes with a different sampling periodicity, and were only subsequently coupled to the caulerpernyne sampling when some correlations were observed. These samples were collected by hand by SCUBA divers. The algal material was sorted into fronds and stolons, dried for $48 \mathrm{~h}$ at $70^{\circ} \mathrm{C}$, then weighed to determine biomass as DW. Caulerpa-specialized herbivores, such as the sea slug Ascobulla fragilis (Jeffreys, 1856) were sorted from samples using a dissecting microscope.

\section{Statistical analysis}

Statistical analyses were carried out using the statistical package SPSS 14.0 for Windows. The statistical signifi- 
cances of the differences between the concentration of caulerpenyne in the fronds and stolons of the three Caulerpa species were evaluated using the ANOVA for two groups test, while two-way ANOVA was used to test for significant differences in the content of caulerpenyne between Caulerpa species and sampling dates for each thallus part (frond, stolon).

The relationships among the biomass and the concentration of caulerpenyne in the thallus part of each Caulerpa species and seawater temperature was evaluated by performing a linear correlation (Pearson) analysis. The relationship between the abundance of Ascobulla fragilis in $C$. prolifera and the biomass and caulerpenyne content of this species were also evaluated by linear correlation. Pearson correlations of caulerpenyne concentration between Caulerpa species were also used to evaluate the temporal coherence of the concentration of caulerpenyne among species.

\section{Results}

The average $[ \pm 1$ standard error (SE)] biomasses (sum of frond and stolons) in the Caulerpa meadows were
$83.9 \pm 10.7 \mathrm{~g}$ algae $\mathrm{DW} \mathrm{m}^{-2}$ for $C$. prolifera, $43.0 \pm 6.3 \mathrm{~g}$ algae DW m ${ }^{-2}$ for $C$. taxifolia and $16.2 \pm 4.2 \mathrm{~g}$ algae DW m $\mathrm{m}^{-2}$ for $C$. racemosa var cylindracea. Both stolon and frond biomasses of all Caulerpa species changed temporally during our study. C. prolifera biomass remained low during the summer months (from July to September 2005) and had maximum values in spring (February 2005 and May 2005 for fronds and February 2005, May 2005 and June 2005 for stolons) (Figure 1A,B). The biomass of $C$. taxifolia fronds showed a clear seasonal pattern, with a maximum at the end of summer (September 2005) and a minimum value at the end of winter (February 2005). The biomass of stolons was higher in summer (May 2005, June 2005 and August 2005) than in the rest of the year, with a maximum stolon biomass peak in May (Figure 1C,D). C. racemosa biomass showed a clear seasonal pattern with maximum values for both fronds and stolons in August 2005, and a minimum in February 2005 for fronds and October 2005 for stolons (Figure 1E,F).

All Caulerpa species had a higher content of caulerpenyne in fronds than in stolons (Table 1). These differences were significant for $C$. prolifera and $C$. taxifolia but not for $C$. racemosa (Table 1). The content of caulerpenyne in fronds and stolons was highest in C. prolifera, while C. racemosa
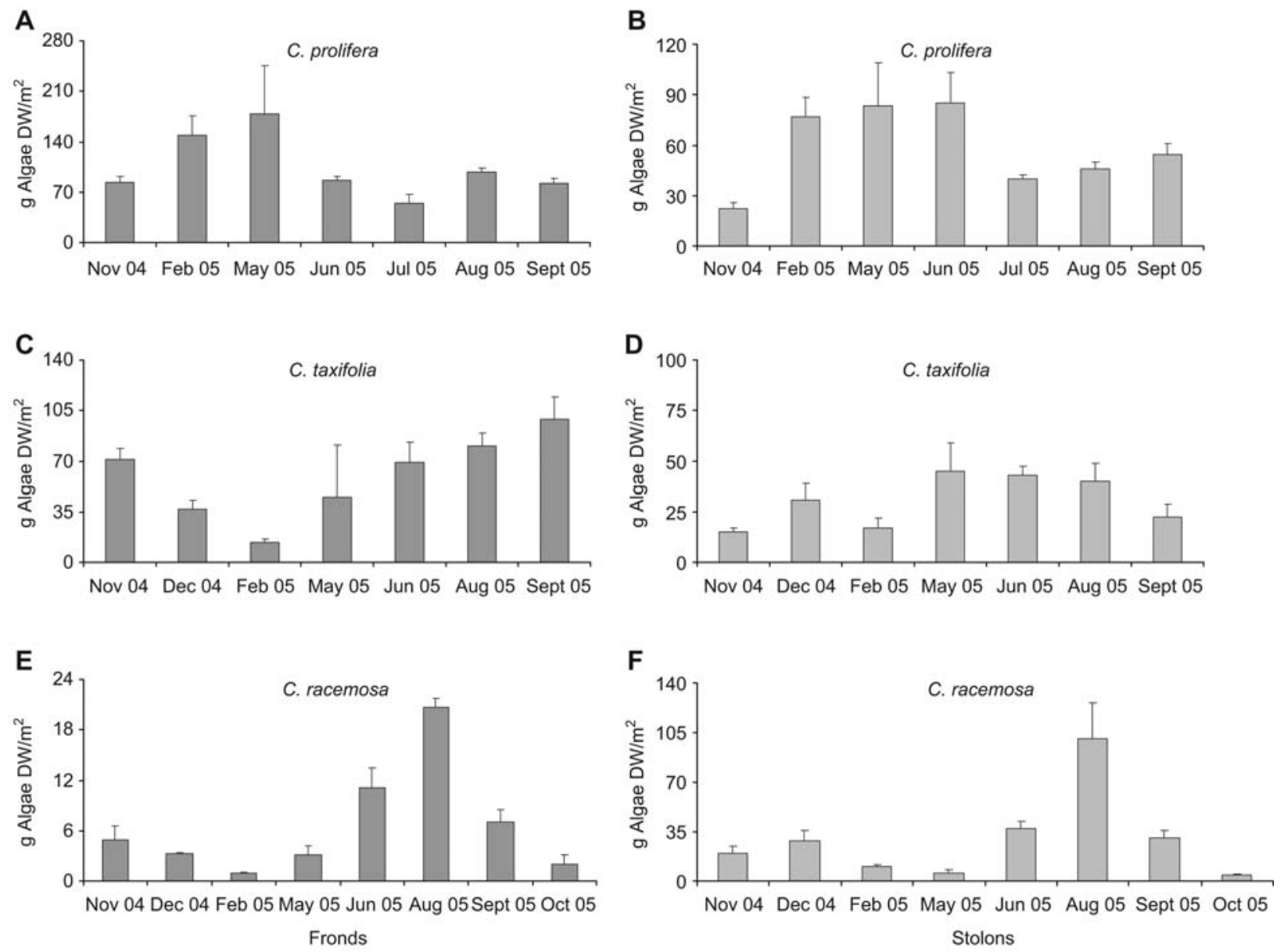

Figure 1 Biomass of fronds (left panels) and stolons (right panels) of three Caulerpa species in Mallorca (western Mediterranean) from November 2004 to October 2005.

Values are means + SE. 
Table 1 Caulerpenyne mean concentration in Caulerpa species (mg caulerpenyne $\mathrm{g}^{-1}$ algal dry weight $\pm \mathrm{SE}$ ).

\begin{tabular}{llll}
\hline Caulerpa species & \multicolumn{2}{l}{ Thallus part } & \\
\cline { 2 - 3 } & Frond & Stolon & \\
\hline C. prolifera & $72.92 \pm 6.44^{\#}$ & $46.35 \pm 2.51^{\#}$ & $* * *$ \\
C. taxifolia & $54.70 \pm 3.21^{*}$ & $12.73 \pm 0.37^{*}$ & $* * *$ \\
C. racemosa & $4.31 \pm 0.79^{+}$ & $2.97 \pm 1.30^{*}$ & $\mathrm{NS}$ \\
\hline
\end{tabular}

Post hoc DMS results compare caulerpenyne concentrations in each tissue among meadows. Different symbols $(\#, *,+)$ denote significantly different groups in columns (ANOVA); *** denotes significant differences between thallus parts within species (in rows) (ANOVA $\mathrm{p}<0.01$ ); NS indicates no significant differences between thallus parts.

Table 2 Two-way ANOVA (factors: Caulerpa species and time) for fronds and stolons.

\begin{tabular}{|c|c|c|c|c|}
\hline \multirow[t]{3}{*}{ Source of variation } & \multicolumn{4}{|c|}{ Thallus part } \\
\hline & \multicolumn{2}{|c|}{ Frond } & \multicolumn{2}{|c|}{ Stolon } \\
\hline & Df & MS & Df & MS \\
\hline Caulerpa species & 2 & $30,840.53^{* * *}$ & 2 & $49,256.71^{* * *}$ \\
\hline Time & 8 & 159.40 & 9 & $2009.51^{* * *}$ \\
\hline Caulerpa species $\times$ time & 16 & $777.92^{* * * *}$ & 18 & $2896.16^{* * *}$ \\
\hline Residual & 81 & 139.02 & 90 & 182.15 \\
\hline
\end{tabular}

*** Denotes significant differences (ANOVA $\mathrm{p}<0.01$ ).

had the lowest levels (Table 1). The content of caulerpenyne was different between Caulerpa species and sampling dates; there was also a significant interaction between species and date (Table 2).

The content of caulerpenyne in fronds of Caulerpa prolifera was lower from May 2005 to October 2005 than during the rest of the year, while the content of caulerpenyne in the stolons showed no clear seasonal pattern (Figure 2A,B). None of the correlations among biomass and caulerpenyne content in the fronds and stolons of this species and temperature of the water were significant (Table 3).

The content of caulerpenyne in fronds of Caulerpa taxifolia was lowest at the end of winter (February 2005) and then reached a maximum value in May 2005 before decreasing slowly until the last sampling date in October 2005. Except for the relatively high values in April 2005, September 2005, and October 2005, the content of caulerpenyne in the stolons of this species did not change during the year (Figure 2C,D). The content of caulerpenyne in fronds of $C$. taxifolia was positively correlated with water temperature but not with frond biomass (Table 3). The content of caulerpenyne in stolons was not correlated with temperature or stolon biomass.

The content of caulerpenyne in fronds of Caulerpa racemosa remained low during the year except for a high value recorded in October 2005. However, the caulerpenyne content in stolons showed clear seasonal pattern, with minimum values at the end of winter (February 2005) and in early spring (March 2005 and April 2005), increasing to reach maximum values at the end of summer (August 2005October 2005) and (Figure 2E,F). The content of caulerpenyne in the stolons of this species was positively correlated with water temperature (Table 3 ).

Ascobulla fragilis was the only Caulerpa-specialized opisthobranch found amongst the three Caulerpa species A. fragilis was more frequent and abundant on $C$. prolifera than in the two non-native Caulerpa species studied, on which it was found on only one sampling date for $C$. taxifolia and two for $C$. racemosa (Table 4). The abundance of $A$. fragilis in $C$. prolifera mats was higher from November to January than during the rest of the year (Table 4 ) and it was positively correlated $(\rho=0.82$, significance $p<0.05)$ with the content of caulerpenyne in the fronds of $C$. prolifera.

The concentration of caulerpenyne in the stolons of Caulerpa prolifera was negatively correlated with those of $C$. taxifolia $(\rho=-0.36$, significance $\mathrm{p}<0.05)$ and $C$. racemosa $(\rho=-0.30$, significance $p<0.05)$, and it was correlated positively between the last two species $(\rho=0.49$, significance $\mathrm{p}<0.01)$. The concentration of caulerpenyne in the fronds was not correlated between Caulerpa species.

\section{Discussion}

Our results indicate that caulerpenyne concentration differs significantly among Caulerpa species, decreasing from $C$. prolifera to $C$. taxifolia and again to $C$. racemosa. The concentration of caulerpenyne was also different between fronds and stolons in $C$. prolifera and $C$. taxifolia but not in $C$. racemosa. The fronds of $C$. prolifera and $C$. taxifolia had higher concentration of caulerpenyne than their respective stolons. Differences in the concentration of caulerpenyne among Caulerpa species has been reported previously by other authors (Paul and Hay 1986, Amade and Lemee 1998, Dumay et al. 2002, Jung et al. 2002, Sureda et al. 2006). The concentrations of caulerpenyne quantified in this study fall within the upper range of the concentrations of this compound reported for these Caulerpa species elsewhere (Table 5). In addition, and similar to previous studies (Amade and Lemee 1998, Dumay et al. 2002), we found that the concentration of caulerpenyne changes during the year.

Temperature and biomass seasonality were not the main factors determining caulerpenyne concentrations in C. prolifera thallus parts. Neither was correlated with caulerpenyne concentration seasonal variations. High densities of Ascobulla fragilis were found in $C$. prolifera mats but not in the other studies of Caulerpa species A. fragilis is a specialized Caulerpa prolifera herbivore that uses caulerpenyne derivates as chemical defence (Gavagnin et al. 1994, Marin and Ros 2004). Caulerpenyne concentration in $C$. prolifera fronds was positively correlated with the abundance of $A$. fragilis. Previous studies concluded that algal toxicity could be increased as result of herbivore pressure, which could drive an increase in concentration in the defensive metabolites in the algae (Van Alstyne 1988, Paul and Van Alstyne 1992, Erickson et al. 2006, Sureda et al. 2009). 
A

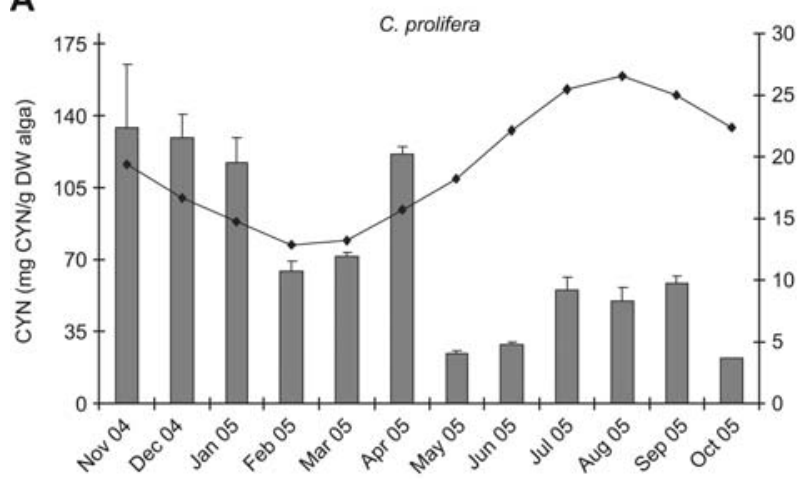

C

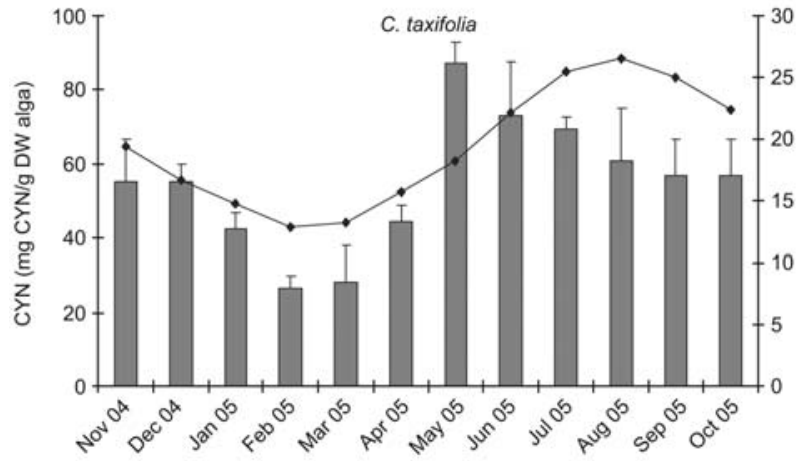

E

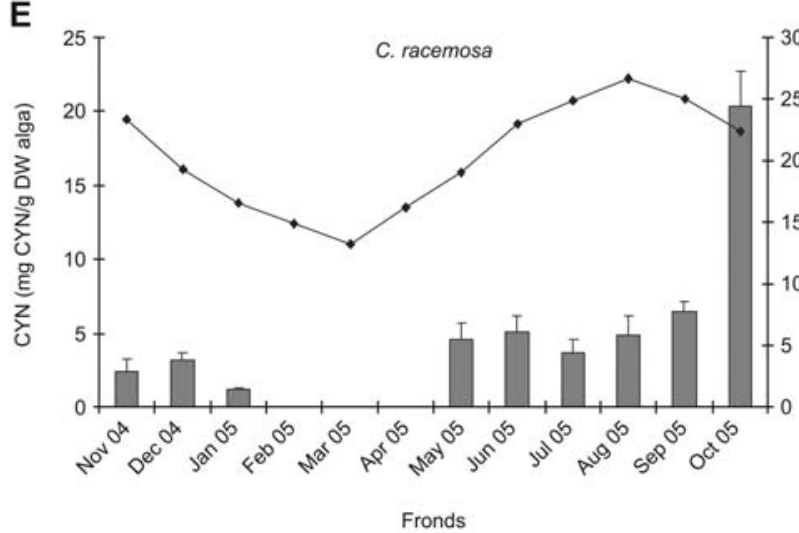

B

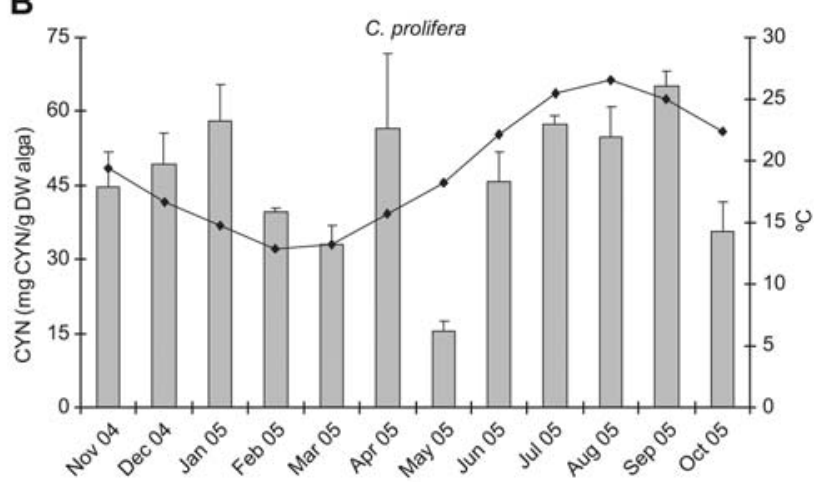

D
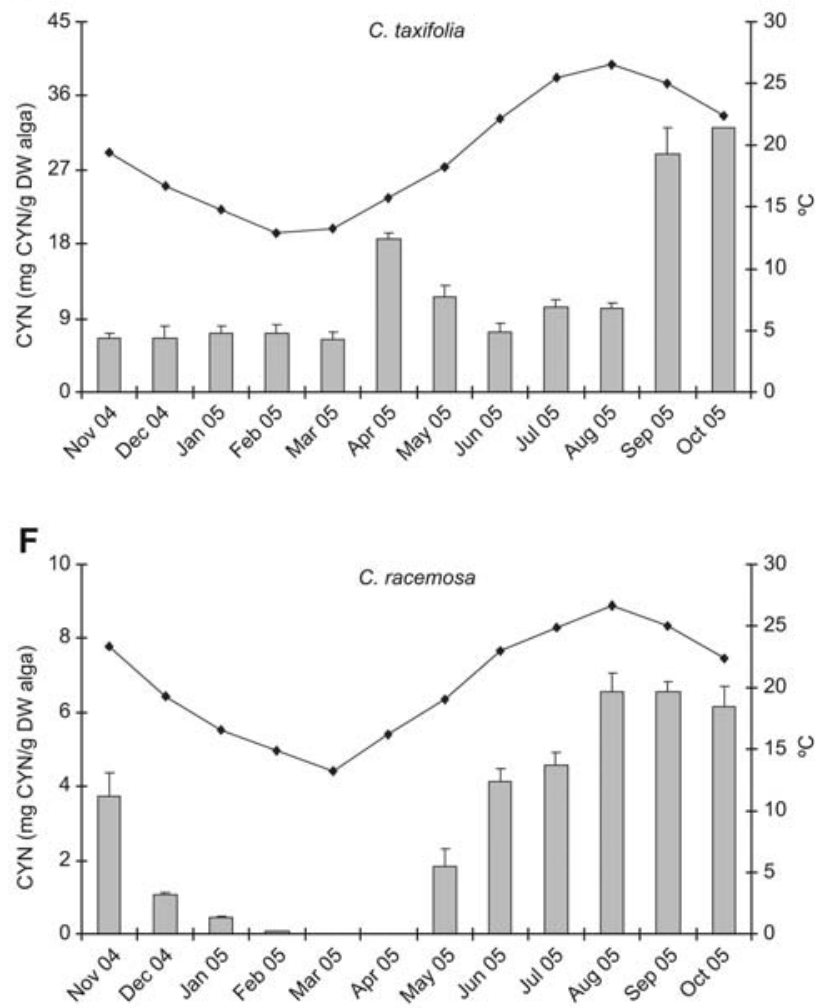

Stolons

Figure 2 Concentration of caulerpenyne (CYN) expressed as $\mathrm{mg} \mathrm{CYN} \mathrm{g}^{-1}$ dry weight of alga in the fronds (left panels) and stolons (right panels) of three Caulerpa species in Mallorca (western Mediterranean) from November 2004 to October 2005.

The solid line with triangles represents temperature of seawater. Caulerpenyne values are mean $+\mathrm{SE}$.

Caulerpenyne concentration in Caulerpa taxifolia was 2-10 times higher in fronds than stolons, depending on the period of the year. In $C$. taxifolia, the highest caulerpenyne concentration was found in May 2005 in fronds and in summer-autumn (September 2005/October 2005) in stolons. The increase in caulerpenyne concentration during spring was observed earlier in stolons (April) than in fronds (May). These values corresponded to a low biomass period of fronds and stolons of $C$. taxifolia and appeared just before the increase in C. taxifolia biomass. C. taxifolia colonization around the Balearic Islands has been patchy and, where present, it does not form dense meadows. Moreover, only a few
C. taxifolia fronds and stolons remain in seagrass meadows over dead Posidonia oceanica rhizomes in winter. An increase in water temperature provides a better environment for the growth of $C$. taxifolia, which increases its biomass and protects the new growth with secondary metabolites. Caulerpenyne concentration in C. taxifolia stolons also exhibited another seasonal pattern, with an important increase at the end of summer. These results are similar to those obtained in previous studies (Amade and Lemee 1998, Dumay et al. 2002), which reported higher caulerpenyne concentration in summer and autumn, but these studies were performed in monospecific Caulerpa meadows that had high 
Table 3 Pearson bivariate correlations between caulerpenyne concentration in thallus parts and biomass and temperature.

\begin{tabular}{llllll}
\hline & Fronds & & & \multicolumn{2}{l}{ Stolons } \\
\cline { 2 - 3 } \cline { 6 - 6 } \cline { 5 - 6 } & Biomass & Temperature & & Biomass & Temperature \\
\hline C. prolifera & NS & NS & & NS & NS \\
C. taxifolia & NS & $0.644^{*}$ & & NS & NS \\
C. racemosa & NS & NS & NS & $0.922^{* *}$ \\
\hline
\end{tabular}

NS denotes no significant correlation; * denotes significance $\mathrm{p}<0.05 ; * *$ denotes significance $\mathrm{p}<0.01$.

biomass values throughout the year. Caulerpenyne concentration in C. taxifolia fronds was positively correlated with temperature; when the temperature was over $18^{\circ} \mathrm{C}$ (May 2005), a significant increase in caulerpenyne concentration occurred. Amade and Lemee (1998) found this important increase in caulerpenyne concentration in June at temperatures over $20^{\circ} \mathrm{C}$ in samples obtained over a rocky substratum in Cap Martin (with high $C$. taxifolia winter biomass).

Caulerpa racemosa is the most recent Caulerpa species in Balearic Islands waters (Ballesteros et al. 1999). It has colonized larger areas around these islands than $C$. taxifolia (personal observations). In agreement with previous works (Dumay et al. 2002, Jung et al. 2002), C. racemosa had lower caulerpenyne concentration than the other two $\mathrm{Cau}$ -
Table 4 Ascobulla fragilis abundance (individuals $\mathrm{m}^{-2}$ ) in Caulerpa mats.

\begin{tabular}{lccc}
\hline Dates & \multicolumn{2}{l}{ Ascobulla fragilis } & \\
\cline { 2 - 4 } & C. prolifera & C. taxifolia & C. racemosa \\
\hline November 2004 & $408 \pm 144.01$ & $16.67 \pm 5.89$ & $33.33 \pm 15.90$ \\
December 2004 & $300 \pm 89.02$ & & $33.33 \pm 23.57$ \\
January 2005 & $442 \pm 123.01$ & & \\
February 2005 & $58 \pm 15.53$ & & \\
May 2005 & $175 \pm 58.00$ & & \\
June 2005 & $67 \pm 43.12$ & & \\
July 2005 & $59 \pm 41.14$ & & \\
August 2005 & $8 \pm 4.12$ & & \\
\hline
\end{tabular}

Values are means \pm SE.

lerpa species studied (Table 5). The influence of temperature on caulerpenyne concentration in $C$. racemosa was observed in stolons (positive correlation). The seasonality observed in caulerpenyne concentration was similar to that described by Dumay et al. (2002) over a 1 year cycle. Caulerpenyne concentration did not differ significantly between fronds and stolons, which suggests that both thallus parts are similarly protected against herbivores.

This study showed different seasonal variations in caulerpenyne content among three Caulerpa species inhabiting the

Table 5 Concentration of caulerpenyne in Caulerpa species.

\begin{tabular}{|c|c|c|c|c|c|c|}
\hline Reference & Caulerpa species & $\begin{array}{l}\text { Caulerpenyne } \\
\text { concentration } \\
\text { in } \\
\text { fronds and } \\
\text { stolons } \\
(\% \circ \mathrm{WW})\end{array}$ & $\begin{array}{l}\text { Caulerpenyne } \\
\text { concentration in } \\
\text { fronds ( } \% \mathrm{DW})\end{array}$ & $\begin{array}{l}\text { Caulerpenyne } \\
\text { concentration in } \\
\text { stolons (\% DW) }\end{array}$ & $\begin{array}{l}\text { Caulerpenyne } \\
\text { concentration } \\
\text { in } \\
\text { fronds and } \\
\text { stolons } \\
(\% \mathrm{DW})\end{array}$ & Location \\
\hline Amico et al. 1978 & C. prolifera & & & & 0.35 & Mediterranean \\
\hline Gavagnin et al. 1994 & C. prolifera & & $0.16-0.5$ & $0.22-0.66$ & & Italy, Naples Bay \\
\hline Jung et al. 2002 & C. prolifera & 6 & & & $3.22^{\mathrm{a}}$ & South France \\
\hline Sureda et al. 2006 & C. prolifera & & & & 4.5 & Balearic Islands, Spain \\
\hline This study & C. prolifera & & $7.29 \pm 0.64$ & $4.64 \pm 0.25$ & & Balearic Islands, Spain \\
\hline Guerriero et al. 1992 & C. taxifolia & 1.95 & & & $0.12^{\mathrm{b}}$ & France, Cap Martin \\
\hline $\begin{array}{l}\text { Amade et al. } 1994 \\
\text { Amade and Lemee }\end{array}$ & C. taxifolia & & & & 0.16 & France, Cap Martin \\
\hline 1998 & C. taxifolia & $1.5-12.5$ & & & $1.16-9.69^{\mathrm{b}}$ & $\begin{array}{l}\text { France, Cap Martin, } \\
10 \text { m depth }\end{array}$ \\
\hline Dumay et al. 2002 & C. taxifolia & $\begin{array}{l}3.70 \\
\text { (max. value) }\end{array}$ & & & $2.87^{\mathrm{b}}$ & Alpes Maritime, France \\
\hline Jung et al. 2002 & C. taxifolia & 6 & & & $4.65^{\mathrm{b}}$ & South France \\
\hline Sureda et al. 2006 & C. taxifolia & & & & 3.0 & Balearic Islands, Spain \\
\hline This study & C. taxifolia & & $5.47 \pm 0.32$ & $1.27 \pm 0.03$ & & Balearic Islands, Spain \\
\hline Meyer and Paul 1992 & C. racemosa & & 0.5 & 0.3 & & Guam \\
\hline Meyer and Paul 1992 & C. racemosa & & 0.75 & 0.25 & & Bahamas \\
\hline Dumay et al. 2002 & C. racemosa & $\begin{array}{l}0.07 \\
\text { (max. value) }\end{array}$ & & & $0.08^{\mathrm{c}}$ & $\begin{array}{l}\text { Alpes Maritimes, } \\
\text { France }\end{array}$ \\
\hline Jung et al. 2002 & C. racemosa & 3 & & & $0.33^{\mathrm{c}}$ & South France \\
\hline This study & C. racemosa & & $0.43 \pm 0.07$ & $0.30 \pm 0.13$ & & Balearic Islands, Spain \\
\hline
\end{tabular}

${ }^{\mathrm{a}}$ Calculated using a WW to DW conversion factor of $0.19 .{ }^{\mathrm{b}}$ Calculated using a WW to DW conversion factor of 0.13 . ${ }^{\mathrm{c}}$ Calculated using a WW to DW conversion factor of 0.09 . 
Balearic Islands under similar seasonal and climate conditions. Caulerpenyne concentrations in stolons of $C$. prolifera were negatively correlated with the caulerpenyne content in stolons of both invasive Caulerpa species as the Pearson results show. Caulerpenyne concentrations in stolons of both invasive Caulerpa species were positively correlated between species, confirming similar trends in the caulerpenyne concentrations for invasive species. The highest caulerpenyne concentrations in stolons were recorded in the native Mediterranean Caulerpa species ( $C$. prolifera). This may be explained as a response to grazing pressure, with $C$. prolifera being more chemically protected against direct herbivory than invasive Caulerpa species. Similarly, Sureda et al. (2009) found an increase in caulerpenyne concentration in $C$. taxifolia fronds grazed by Bittium reticulatum (da Costa, 1778). This increase in caulerpenyne concentration in fronds was reached in less than a week after the introduction of the Caulerpa consumer under controlled conditions (Sureda et al. 2009). Therefore, a time-lag between the presence of $A$. fragilis and caulerpenyne concentration in $C$. prolifera is not expected. To explain caulerpenyne production, factors other than herbivores, such as epiphytes, must be considered. Epiphytism of Caulerpa species by other macroalgae might also activate caulerpenyne production as a method of reducing the growth of epiphytes (Box et al. 2008). Further research is needed to determine the possible real effects of epiphytes on calulerpenyne production.

In invasive Caulerpa species, temperature was correlated with the concentration of caulerpenyne in fronds of $C$. taxifolia and stolons of $C$. racemosa. Previous studies have also shown the highest concentrations of caulerpenyne to be coincident with higher temperatures (Amade and Lemee 1998, Dumay et al. 2002). C. taxifolia fronds have higher caulerpenyne concentrations than stolons, while in C. racemosa, similar concentrations of caulerpenyne were found in both fronds and stolons. Each Caulerpa species showed the highest concentration of caulerpenyne in the thallus part where the highest proportion of biomass is recorded ( $C$. prolifera and $C$. taxifolia highest biomass and caulerpenyne concentration in fronds and $C$. racemosa had similar caulerpenyne concentration in both tissues). Field results for $C$. prolifera did not reflect the seasonal cycle in fronds and stolons with the temperature in our region of study, and the presence of small Caulerpa herbivores may influence caulerpenyne production.

All three Caulerpa species contain higher caulerpenyne concentrations in fronds than stolons, probably due to the photosynthetic activity and higher exposure of fronds to consumers than stolons. This is the only coincidence between the three species because, under similar climate conditions and seasonality, $C$. prolifera is the species with the highest caulerpenyne concentration in Balearic Islands followed by C. taxifolia and C. racemosa. Despite the fact that the expansion of invasive Caulerpa species does not seem to depend on the caulerpenyne concentration, the massive Caulerpa biomass degradation observed in invasive species, could lead to a caulerpenyne accumulation (or its derivates) in the substratum that may affect possible competitors, as previously reported for Cymodocea nodosa (Ucria) Ascherson (Raniello et al. 2007). Temperature is an important factor influencing the caulerpenyne concentration in invasive Caulerpa species, but not in $C$. prolifera. However, the concentration of caulerpenyne in $C$. prolifera fronds was correlated with the abundance of the specialised herbivore Ascobulla fragilis, which might suggest that the feeding activity of this herbivore influences the concentration of caulerpenyne. Therefore, further studies are needed to evaluate different aspects of the physiology and seasonality on the toxicity of Caulerpa, on the biotic interactions with other plant species, on the effects of temperature and on herbivore pressure to discern the main factors involved in caulerpenyne production.

\section{Acknowledgements}

The authors are grateful to Philip Amade for technical assistance. This work was supported by the research projects "Expansión de Caulerpa prolifera, C. taxifolia y C. racemosa en el Mediterráneo: dinámica clonal, producción y destino de la producción", (REN2002-00701/MAR) and "Macroalgas marinas invasoras en las Islas Baleares: Evaluación de riesgos y efectos en comunidades bentónicas" (CTM2005-01434/MAR) of the Ministerio de Educación y Ciencia. A. Box was supported by an I3P FSE postgraduate fellowship awarded by Consejo Superior de Investigaciones Científicas. Marina de Cala D’Or (Cala D’Or, Santanyí, Mallorca) kindly made available its harbour facilities for executing this study. We are most grateful to Piluca Sariera for her help during the entire project.

\section{References}

Amade, P. and R. Lemee. 1998. Chemical defence of the Mediterranean alga Caulerpa taxifolia: variations in caulerpenyne production. Aquat. Toxicol. 43: 287-300.

Amade, P., R. Valls, R. Bouaiacha, R. Lemee and J. Artaud. 1994. Methodes de dosage de la caulerpenyne produite par Caulerpa taxifolia. In: (C.F. Boudouresque, A. Meinesz and V. Gravez, eds.) First International Workshop on Caulerpa taxifolia. GIS Posidonies Publ., Marseilles. pp 163-167.

Amico, V., G. Oriente, M. Piattelli, C. Tringali, E. Fattorusso, S. Magno and L. Matol. 1978. Caulerpenyne, an unusual sesquiterpenoid from green alga Caulerpa prolifera. Tetrahedron Lett. 38: 3593-3595.

Argyrou, M., A. Demetropoulos and M. Hadjichristophorou. 1999. Expansion of the macroalga Caulerpa racemosa and changes in softbottom macrofaunal assemblages in Moni Bay, Cyprus. Oceanol. Acta 22: 517-528.

Balata, D., L. Piazzi and F. Cinelli. 2004. A comparison among assemblages in areas invaded by Caulerpa taxifolia and $C$. racemosa on a subtidal Mediterranean rocky bottom. PSZNI Mar. Ecol. 25: 1-13.

Ballesteros, E., A.M. Grau and F. Riera. 1999. Caulerpa racemosa (Forsskål) J. Agardh (Caulerpales, Chlorophyta) in Mallorca (Western Mediterranean). Boll. Soc. Hist. Nat. Illes Balears 42: 63-69.

Barbier, P., S. Guise, P. Huitorel, P. Amade, D. Pesando, C. Briand and V. Peyrot. 2001. Caulerpenyne from Caulerpa taxifolia has an antiproliferative activity on tumor cell line SK-N-SH and modifies the microtubule network. Life Sci. 70: 415-429. 
Boudouresque, C.F. 1998. Follow up of biological introduction in the sea. Biofutur 179: 76-78.

Boudouresque, C.F. and M. Verlaque. 2002. Biological pollution in the Mediterranean Sea: invasive versus introduced macrophytes. Mar. Pollut. Bull. 44: 32-38.

Boudouresque, C.F., A. Meinesz, M.A. Ribera and E. Ballesteros. 1995. Spread of the green alga Caulerpa taxifolia (Caulerpales, Chlorophyta) in the Mediterranean: possible consequences of a major ecological event. Sci. Mar. 59: 21-29.

Box, A., A. Sureda, J. Terrados, A. Pons and S. Deudero. 2008. Antioxidant response and caulerpenyne production of the alien Caulerpa taxifolia (Vahl) epiphytized by the invasive algae Lophocladia lallemandii (Montagne). J. Exp. Mar. Biol. Ecol. 363: 24-28.

Buia, M.C., M.C. Gambi, A. Terlizzi and L. Mazzella. 2001. Colonization of Caulerpa racemosa along the southern italian coast: I. Distribution, phenological variability and ecological role. In: (V. Gravez, S. Ruitton, C.F. Boudouresque, L. Le Direac'h and A. Meinesz, eds.). Fourth International Workshop on Caulerpa taxifolia. GIS Posidonies Publ., Marseille. pp. 352-360.

Ceccherelli, G. and D. Campo. 2002. Different effects of Caulerpa racemosa on two co-occurring seagrasses in the Mediterranean. Bot. Mar. 45: 71-76.

Devillele, X. and M. Verlaque. 1995. Changes and degradation in a Posidonia oceanica bed invaded by the introduced tropical alga Caulerpa taxifolia in the North-Western Mediterranean. Bot. Mar. 38: 79-87.

Dumay, O., G. Pergent, C. Pergent-Martini and P. Amade. 2002. Variations in caulerpenyne contents in Caulerpa taxifolia and Caulerpa racemosa. J. Chem. Ecol. 28: 343-352.

Erickson, A.A., V.J. Paul, K.L. Van Alstyne and L.M. Kwiatkowski. 2006. Palatability of macroalgae that use different types of chemical defenses. J. Chem. Ecol. 32: 1883-1895.

Gavagnin, M., A. Marin, F. Castelluccio, G. Villani and G. Cimino. 1994. Defensive relationships between Caulerpa prolifera and its shelled sacoglossan predators. J. Exp. Mar. Biol. Ecol. 175: 197-210.

Guerriero, A., A. Meinesz, M. Dambrosio and F. Pietra. 1992. Isolation of toxic and potentially sesquiterpenes and monoterpenes from the tropical green seaweed Caulerpa taxifolia which has invaded the region of Cap Martin and Monaco. Helvetica Chem. Acta 75: 689-695.

Hay, M.E. and W. Fenical. 1988. Marine plant-herbivore interactions: the ecology of chemical defense. Annu. Rev. Ecol. Syst. 19: 111-145.

Jung, V. and G. Pohnert. 2001. Rapid wound-activated transformation of the green algal defensive metabolite caulerpenyne. Tetrahedron 57: 7169-7172.

Jung, V., T. Thibaut, A. Meinesz and G. Pohnert. 2002. Comparison of the wound-activated transformation of caulerpenyne by invasive and noninvasive Caulerpa species of the Mediterranean. $J$. Chem. Ecol. 28: 2091-2105.

Lemee, R., C.F. Boudouresque, J. Gobert, P. Malestroit, X. Mari, A. Meinesz, V. Menager and S. Ruitton. 1996. Feeding behaviour of Paracentrotus lividus in the presence of Caulerpa taxifolia introduced in the Mediterranean Sea. Oceanol. Acta 19: 245-253.

Mack, R.N., D. Simberloff, W.M. Lonsdale, H. Evans, M. Clout and F.A. Bazzaz. 2000. Biotic invasions: causes, epidemiology, global consequences, and control. Ecol. Appl. 10: 689-710.

Marin, A. and J. Ros. 2004. Chemical defenses in sacoglossan opisthobranchs: taxonomic trends and evolutive implications. Sci. Mar. 68: 227-241.
Meinesz, A. 2004. Caulerpa taxifolia continues its invasion. Biofutur 244: 41-46.

Meinesz, A. and B. Hesse. 1991. Introduction of the tropical alga Caulerpa taxifolia and its invasion of the Northwestern Mediterranean. Oceanol. Acta 14: 415-426.

Meinesz, A., J. Devaugelas, B. Hesse and X. Mari. 1993. Spread of the introduced tropical green alga Caulerpa taxifolia in Northern Mediterranean waters. J. Appl. Phycol. 5: 141-147.

Meinesz, A., T. Belsher, T. Thibaut, B. Antolic, K.B. Mustapha, C.F. Boudouresque, D. Chiaverini, F. Cinelli, J.M. Cottalorda, A.S. Djellouli, A. El Abed, C. Orestano, A.M. Grau, L. Ivesa, I. Vaugelas, N. Zavodnik and A. Zuljevic. 2001. The introduced green alga Caulerpa taxifolia continues to spread in Mediterranean. Biol. Invasions 3: 201-210.

Meyer, K.D. and V.J. Paul. 1992. Intraplant variation in secondary metabolite concentration in 3 species of Caulerpa (Chlorophyta, Caulerpales) and its effects on herbivorous fishes. Mar. Ecol. Prog. Ser. 82: 249-257.

Parent-Massin, D., V. Fournier, P. Amade, R. Lemee, M. Durandclement, C. Delescluse and D. Pesando. 1996. Evaluation of the toxicological risk to humans of caulerpenyne using human hematopoietic progenitors, melanocytes, and keratinocytes in culture. J. Toxicol. Env. Health 47: 47-59.

Paul, V.J. 1992. Ecological roles of marine natural products. Cornell University Press, London. $245 \mathrm{pp}$.

Paul, V.J. and W. Fenical. 1986. Chemical defense in tropical green algae, Order Caulerpales. Mar. Ecol. Prog. Ser. 34: 157-169.

Paul, V.J. and M.E. Hay. 1986. Seaweed susceptibility to herbivory - chemical and morphological correlates. Mar. Ecol. Prog. Ser. 33: 255-264.

Paul, V.J. and K.L. Van Alstyne. 1992. Activation of chemical defenses in the tropical green algae Halimeda spp. J. Exp. Mar. Biol. Ecol. 160: 191-203.

Pesando, D., R. Lemee, C. Ferrua, P. Amade and J.P. Girard. 1996. Effects of caulerpenyne, the major toxin from Caulerpa taxifolia on mechanisms related to sea urchin egg cleavage. Aquat. Toxicol. 35: 139-155.

Piazzi, L., D. Balata, G. Ceccherelli and F. Cinelli. 2001. Comparative study of the growth of the two co-occurring introduced green algae Caulerpa taxifolia and Caulerpa racemosa along the Tuscan coast (Italy, western Mediterranean). Cryptogam. Algol. 22: 459-466.

Pohnert, G. and V. Jung. 2003. Intracellular compartmentation in the biosynthesis of caulerpenyne: study on intact macroalgae using stable-isotope-labeled precursors. Org. Lett. 5: 50915093.

Raniello, R., E. Mollo, M. Lorenti, M. Gavagnin and M.C. Buia. 2007. Phytotoxic activity of caulerpenyne from the Mediterranean invasive variety of Caulerpa racemosa: a potential allelochemical. Biol. Invasions 9: 361-368.

Sakai, A.K., F.W. Allendorf, J.S. Holt, D.M. Lodge, J. Molofsky, K.A. With, S. Baughman, R.J. Cabin, J.E. Cohen, N.C. Ellstrand, D.E. Mccauley, P. O'Neil, I.M. Parker, J.N. Thompson and S.G. Weller. 2001. The population biology of invasive species. Annu. Rev. Ecol. Syst. 32: 305-332.

Sureda, A., A. Box, M. Ensenat, E. Alou, P. Tauler, S. Deudero and A. Pons. 2006. Enzymatic antioxidant response of a labrid fish (Coris julis) liver to environmental caulerpenyne. Comp. Biochem. Physiol. 144 C: 191-196.

Sureda, A., A. Box, S. Deudero and A. Pons. 2009. Reciprocal effects of caulerpenyne and intense herbivorism on the antioxidant response of Bittium reticulatum and Caulerpa taxifolia. Ecotoxicol. Environ. Saf. 72: 795-801. 
Van Alstyne, K.L. 1988. Herbivore grazing increases polyphenolic defenses in the intertidal brown alga Fucus distichus. Ecology 69: 655-663.

Verlaque, M. and P. Fritayre. 1994. Mediterranean algal communities are changing in the face of the invasive alga Caulerpa taxifolia (Vahl). Oceanol. Acta 17: 659-672.

Verlaque, M., C.F. Boudouresque, A. Meinesz and V. Gravez. 2000. The Caulerpa racemosa complex (Caulerpales, Ulvophyceae) in the Mediterranean Sea. Bot. Mar. 43: 49-68.

Verlaque, M., C. Durand, J.M. Huisman, C.F. Boudouresque and Y. Le Parco. 2003. On the identity and origin of the Mediterranean invasive Caulerpa racemosa (Caulerpales, Chlorophyta). Eur. J. Phycol. 38: 325-339.

Verlaque, M., J. Afonso-Carrillo, M.C. Gil-Rodriguez, C. Durand, C.F. Boudouresque, and Y. Le Parco. 2004. Blitzkrieg in a marine invasion: Caulerpa racemosa var. cylindracea (Bryopsidales, Chlorophyta) reaches the Canary Islands (north-east Atlantic). Biol. Invasions 6: 269-281.

Received 6 February, 2009; accepted 9 April, 2010; online first 15 June, 2010 